Article

\title{
Long-Term Sustainability Implications of Diverse Commercial Pollinator Mixtures for the Conservation Reserve Program
}

\author{
Amanda J. Ashworth ${ }^{1, *(\mathbb{D}}$, Taylor Adams ${ }^{1}$ and Alayna Jacobs ${ }^{2}$ \\ 1 Poultry Production and Product Safety Research Unit, U.S. Department of Agriculture-Agricultural Research \\ Service, Fayetteville, AR 72701, USA; taylor.adams@usda.gov \\ 2 Integrated Plant and Soil Sciences, University of Kentucky, Lexington, KY 42071, USA; alayna.jacbos@uky.edu \\ * Correspondence: amanda.ashworth@usda.gov; Tel.: +1-479-575-6916
}

Citation: Ashworth, A.J.; Adams, T.; Jacobs, A. Long-Term Sustainability Implications of Diverse Commercia Pollinator Mixtures for the Conservation Reserve Program. Agronomy 2022, 12, 549. https:// doi.org/10.3390/agronomy12030549

Academic Editor:

Francis Drummond

Received: 28 January 2022

Accepted: 19 February 2022

Published: 23 February 2022

Publisher's Note: MDPI stays neutral with regard to jurisdictional claims in published maps and institutional affiliations.

Copyright: (C) 2022 by the authors. Licensee MDPI, Basel, Switzerland. This article is an open access article distributed under the terms and conditions of the Creative Commons Attribution (CC BY) license (https:// creativecommons.org/licenses/by/ $4.0 /)$.

\begin{abstract}
The persistence of Conservation Reserve Program (CRP) seed mixtures following planting is crucial for the long-term support of pollinator habitat; however, the role of disturbance regimes and their interactions in supporting this ecosystem service are largely unknown. This study set out to evaluate how ecological disturbances (prescribed burn, light disking, or fallow control) and commercially available diverse species mixtures ('Hamilton', 'Bamert', and 'Holland') affect pollinator habitat and the flowering period of commonly used CRP species mixtures. Specifically, three pollinator species mixtures were assessed for plant stand dynamics (plant density, yield, and dualuse pollinator-lignocellulosic feedstock potential); the resulting soil properties; and the total bloom count during the growing season. Following 5 years after their establishment, the proportions of flowering pollinator species varied by disturbance regime $\times$ seed mixture $(p<0.05)$, with the burned Hamilton and disked Holland plots having the greatest pollinator species percentages. Overall, if the long-term stability of pollinator blooms is a key consideration for management, the Hamilton mixture should be disturbed via prescribed burning, while the Holland mixture should be disked, owing to a species-specific disturbance regime preference. However, post-senescence yield and soil health properties did not vary $(p>0.05)$ across pollinator mixtures or disturbance regimes. Pollinator mixtures could also be harvested as a lignocellulosic feedstock without damaging pollinator habitat and providing comparable biomass for regional feedstocks; however, seeding mixtures and disturbance regimes should be considered based on desired residue usage for long-term sustainable CRP pollinator habitat.
\end{abstract}

Keywords: pollinator habitat; disturbance regimes; pollinator diversity; seeding mixture

\section{Introduction}

Insect pollination is vital to the economic and ecologic sustainability of many food crops grown in the United States [1-6]; however, the populations of bees and other beneficial insects have sharply declined in recent years [7-9]. As a result, the United States Department of Agriculture (USDA) has encouraged private landowners to implement conservation practices aimed at maintaining or establishing pollinator habitat, known as the Conservation Reserve Program (CRP) established in 1985 [10]. The USDA's Farm Service Agency administers the CRP, which provides annual financial assistance payments for replacing environmentally sensitive land in agricultural production with species that improve environmental health and quality. The CRP is the largest conservation program in the United States at 9.6 million ha, with the cumulative benefits including improved water quality, reduced soil erosion, and reduced wildlife habitat loss [10,11].

One available CRP practice is 'CP42 Pollinator Habitat', which is designed to improve access to pollinator food sources such as blooming flowers and native plant structural support for insects and other pollinator species [6,10]. Another benefit of this program is the attraction of insects that are predators or parasites of crop pests, which can reduce 
the reliance on pesticides across landscapes [11,12]. Practice specifications require a seed mixture of nine pollinator-friendly species, with three species blooming during the spring, summer, and fall (April-15 June, 15 June-July, and August-October) [6]. In addition, CP42 plantings must be maintained for 10 years with a mid-contract management requirement, i.e., implementing a cultural disturbance to stimulate herbaceous blooming plant species, limit woody plant encroachment, and limit surface plant residue [6]. However, it is largely unknown how these required disturbance regimes interact to extend bloom periods and pollinator mix persistence.

Without disturbance, early successional habitats, such as those favorable for herbaceous pollinator species, are rapidly replaced by more stable plant communities [13]. Disturbance promotes the maintenance of small areas of bare ground, as these are desired sites for native ground-nesting bees and other solitary insect pollinators [14]. Burning and disking are examples of disturbances that have been shown to stimulate plant growth and diversity. Burning residues lead to the ash-bed effect [15], which increases soil pH and $\mathrm{K}$ and reduces crop disease incidence and weed pressure $[16,17]$. However, long-term losses of $\mathrm{N}, \mathrm{P}$, and $\mathrm{S}$ may also occur, despite the quick release of inorganic $\mathrm{N}$ and $\mathrm{P}[15,18,19]$. Furthermore, burning may reduce the cumulative organic matter and $\mathrm{C}$ of the soil, since plant residues are not deposited on the soil surface [20]. Disking is another disturbance that can promote plant growth, homogenize the soil plow layer, and affect soil physical and chemical properties. Disking offers advantages such as organic matter mixing, a reduction in herbicide use, and improvements to seed germination $[15,20]$.

Through assisting bees and other native populations by providing pollen and nectar via flowers and forbs, the CP42 Pollinator Habitat practice may help to secure the sustainability of future food crop yield. However, the long-term effects of disturbance regimes on select seed mixtures are largely unknown. Thus, the objective of this study was to evaluate the effects of ecological disturbances (prescribed burn, light disking, or fallow control) on pollinator growth and flowering habitat of commercially available species mixtures. Specifically, three pollinator species mixtures were assessed on their plant stand dynamics (plant density, yield stability, and niche differentiation); the resulting soil properties; and the total flowering period under diverse mixtures.

\section{Materials and Methods}

\subsection{Site Description}

The study was conducted at the Natural Resources Conservation Service Plant Materials Center located in Booneville, $\mathrm{AR},\left(35.05^{\circ} \mathrm{N},-93.59^{\circ} \mathrm{W}\right)$, situated in Major Land Resource Area 118A, Arkansas Valley and Ridges, Eastern Part, in the Land Resource Region N, East and Central Farming and Forest Region [21]. Soil at this site is classified as a Leadvale silt loam (Fine-silty, siliceous, semiactive, thermic Typic Fragiudults) [22] and the area has an annual total precipitation of $126.5 \mathrm{~cm}$ and an average annual temperature of $15.6^{\circ} \mathrm{C}$ [21]. The study's site management history included three years of commodity wheat (Triticum aestivum L.) crops. The conversion of this field from annual cash crop production and annual tillage operations mimicked situations where CRP Pollinator Habitat areas are be planted on working farms.

\subsection{Experimental Design and Treatment Applications}

This experiment utilized a two factorially arranged treatment arrangement in a randomized complete block design with three replicates. Seedbeds were prepared in February 2012 by disking and harrowing the designated plot area. Weeds in the plots were chemically killed with glyphosate (N-(phosphonomethyl) glycine) prior to planting. Seed mixtures were then broadcast seeded at $1.12 \mathrm{~kg} \mathrm{ha}^{-1}$ with a Kincaid Precision Cone (Haven, KS, USA) and rolled to ensure proper planting depth. No fertilizer or lime was applied during the study. Three commercially available pollinator mixtures (Bamert, Muleshoe, TX; Hamilton, Elk Creek, MO; Holland, Elkins, AR; Supplementary Table S1) were planted in a $2090 \mathrm{~m}^{2}$ block in March 2012, and replicated thrice, with each plot $\left(9.1 \times 9.1 \mathrm{~m} ; 83.6 \mathrm{~m}^{2}\right)$ 
receiving disturbance regimes, and a $9 \mathrm{~m}$ buffer around each experimental unit. The following were criteria for selecting seed mixtures and rates: (1) must contain 9 species of pollinator-friendly flowering wildflowers, legumes, and/or shrubs (native to Arkansas or surrounding states); (2) adapted to USDA Plant Hardiness Zones 6 7; (3) of those 9 aforementioned species, at least 3 species will bloom during the periods of April-15 June, 15 June-July, and August-October; and (4) seeding rate was required at least 1.3-2.8 pure live seeds per $\mathrm{m}^{2}$.

In the spring of 2015, disturbance regimes (prescribed burn, light disking, or a nondisturbed control) were implemented, and then repeated in the spring of 2017. Prescribed burns were implemented with a drip torch using 80\% diesel and 20\% gasoline, while plots assigned to disking treatments were disked with two passes with a Frontier (John Deere, Moline, IL, USA) leveling disk in the early spring.

\subsection{Data Collection}

Response variables were collected on the experimental units $(9.1 \times 9.1 \mathrm{~m})$. Specifically, bloom data of flowering species were collected on 25 April, 15 May, 31 May, 13 June, and 31 July in 2013 and on 19 May and 17 June in 2014. In 2015, bloom data were collected on 6 May, 16 May, 2 June, and 30 June, and on 10 May, 24 May, and 7 June in 2017. These data were collected by counting the total number of different species flowering (defined as $>90 \%$ reproductive stage) during the sampling date within the entire plot.

Biomass samples were collected on 21 October 2016, and 11 October 2017, for yield and nutritive value determination. Four $1 \mathrm{~m}^{2}$ samples were hand harvested to $4 \mathrm{~cm}$ stubble height per plot. Biomass grab samples (1-2 kg) were collected, weighed, and dried at $55{ }^{\circ} \mathrm{C}$ in a batch oven to determine the moisture content. For each plot, representative soil samples were collected, in conjunction with biomass sampling, to represent pre- and post-disturbance. Six random, $2 \mathrm{~cm}$ push probe soil samples from the 0 to $15 \mathrm{~cm}$ depth were collected on a per plot basis, composited in a bucket, and dried in at $70{ }^{\circ} \mathrm{C}$ for $48 \mathrm{~h}$.

Plant community composition was estimated on 2 June 2016, and 7 June 2017, using a 0.75 by $0.75 \mathrm{~m}$ Vogel grid [23]. Four frequency counts (100 cells in total) were taken in each plot. Counts were multiplied by 0.4 as according to [23], based on the likelihood of one plant per cell to estimate plant density per $\mathrm{m}^{2}$ and then averaged over three blocks.

\subsection{Sample Analysis}

After drying, biomass samples were ground using a Wiley Mini-Mill (Thomas Scientific, Swedesboro, NJ, USA) to pass through a $1 \mathrm{~mm}$ sieve. Total C and N were determined via high-temperature combustion using a VarioMax $\mathrm{CN}$ analyzer (Elementar Americas, Ronkonkoma, NY, USA). For elemental analysis, samples were digested with concentrated $\mathrm{HNO}_{3}$ and $\mathrm{H}_{2} \mathrm{O}_{2}$ and subsequently analyzed by inductively coupled argonplasma spectrometry (ICP, Agilent Technologies, Santa Clara, CA, USA). Lignin, acid-, and neutral-digestible fiber were determined using an ANKOM 200 Fiber Analyzer (ANKOM Technologies, Macedon, NY, USA) [24]. Total ash was determined based on ASTM standard E1755-01 [25]. In total, $1 \mathrm{~g}$ of ground sample was placed in an oven-dried porcelain crucible overnight at $105^{\circ} \mathrm{C}$. Crucibles were then placed in a muffle furnace at $575^{\circ} \mathrm{C}$ for $4 \mathrm{~h}$. A total time of $4.5 \mathrm{~h}$ after the starting of the furnace, crucibles were removed and cooled to room temperature in a glass desiccator. The material retained in the crucible was weighed.

Soil samples were ground with a mortar and pestle and allowed to pass through a $2 \mathrm{~mm}$ sieve for later determination of soil texture using a modified hydrometer [26]. Total $\mathrm{C}$ and $\mathrm{N}$ concentrations were measured by high-temperature combustion using a VarioMax $\mathrm{CN}$ analyzer (Elementar Americas, Mt. Laurel, NJ, USA), while water pH and electrical conductivity were determined potentiometrically using a 1:10 soil mass/water volume mixture. Mehlich-3-extractable (M3) and water-soluble (WS) nutrient concentrations (i.e., $\mathrm{Al}, \mathrm{As}, \mathrm{B}, \mathrm{Ca}, \mathrm{Cd}, \mathrm{Co}, \mathrm{Cr}, \mathrm{Cu}, \mathrm{Fe}, \mathrm{K}, \mathrm{Mg}$, Mn, Mo, Na, Ni, P, Pb, S, Se, Ti, and Zn) were determined using a 1:10 soil mass/extractant solution volume ratio [27] and analyzed by ICP (Agilent Technologies, Santa Clara, CA, USA). 


\subsection{Analysis of Data and Model Development}

Analysis of variance (ANOVA) tests of explanatory variables for soil (i.e., sand, silt, clay, EC, pH, C, N, and M3/WS Al, As, B, Ca, Cd, Co, Cr, Cu, Fe, K, Mg, Mn, Mo, Na, $\mathrm{Ni}, \mathrm{P}, \mathrm{Pb}, \mathrm{S}, \mathrm{Se}, \mathrm{Ti}$, and $\mathrm{Zn}$ ), plant composition, total number of flowering species (bloom count), pollinator plant quality (N, C, NDF, ADF, Lignin, Ash Al, As, B, Ca, Cd, Co, Cr, $\mathrm{Cu}, \mathrm{Fe}, \mathrm{K}, \mathrm{Mg}$, Mn, Mo, $\mathrm{Na}, \mathrm{Ni}, \mathrm{P}, \mathrm{Pb}, \mathrm{S}, \mathrm{Se}, \mathrm{Ti}$, and $\mathrm{Zn}$ ) and yield were performed using the MIXED procedure of SAS (SAS V9.3; SAS Inst. Cary, NC, USA) to determine how pollinator mixtures and disturbance regimes affected the plant and soil parameters. In each model, factorially arranged treatments (pollinator mixtures and disturbance regimes) were considered fixed effects, with replication and year considered random effects. However, for bloom count, the analysis year was considered to be a fixed effect in order to control for the effects of time-invariant variables with time-invariant effects by adding a fixed amount variation to the models. For the flowering species data, sampling date was considered a repeated measure. For the repeated measure, an autoregressive covariance was used and the denominator degrees of freedom for the Type III F-test were adjusted with the Kenward-Roger method [28]. Given that the -2 log-likelihood changed under the repeated-measure analysis and the autoregressive correlation value (0.24) indicated a correlation among observations, an autoregressive covariance was included. When effects or interaction confluences were found, mean separation was performed using the SAS macro 'pdmix800' [29] with Fisher's least significant difference (LSD) test at a Type I error rate of $5 \%$ [30].

\section{Results}

\subsection{Environmental Factors Affecting Pollinator Habitat Persistence and Productivity}

The site's annual average precipitation is $126.5 \mathrm{~cm}$ [31], but the amount received was below average in 2012, 2014, 2016, and $2017(106.1 \mathrm{~cm}, 124 \mathrm{~cm}, 100 \mathrm{~cm}$, and $111.1 \mathrm{~cm}$, respectively) [31,32]. Every year of the study, except 2014, had a greater mean annual temperature than the $30 \mathrm{yr}$ average. The mean warmest year was 2012 , at $18.1^{\circ} \mathrm{C}$, which is $2.5^{\circ} \mathrm{C}$ greater than the $30 \mathrm{yr}$ average $\left(15.6^{\circ} \mathrm{C}\right)$ [31]. The coolest year, 2014 , had a mean annual temperature of $15.1^{\circ} \mathrm{C}$ [32]. The coldest temperature $\left(-7.8^{\circ} \mathrm{C}\right)$ was recorded twice, on 6 February 2014, and 7 January 2017, while the warmest temperature measured during the study $\left(33.3^{\circ} \mathrm{C}\right)$ was observed six times, all from 20 July-4 August 2012. Additionally, the 16 hottest days and 22 of the 23 hottest days of the study occurred during summer 2012 [32]. The extremely hot summer and below average rainfall in 2012 may have inhibited the establishment of all three of the pollinator mixtures. Consequently, water stress at flowering could affect seed development and thus impact future propagation.

The soil environment was assessed to evaluate the potential impacts of long-term pollinator mixtures and disturbance regimes. The only soil properties measured that differed $(p<0.05)$ either by seed mixture (WS Na) or by disturbance (M3 Co) also varied by seed mixture $\times$ disturbance (Table 1$)$.

Across years, the greatest $(p<0.05)$ WS Al content was measured in the disked Hamilton plots, which did not differ $(p>0.05)$ from the burned Holland plots. The greatest $(p<0.05)$ WS Na content was measured in the burned Hamilton plots (Table 1). Burning aboveground vegetation was expected to lead to the ash-bed effect and increased soil mineral availability $[15,19]$. However, no widespread differences by seeding mixture or by disturbance or by mixture $\times$ disturbance were observed in this study. 
Table 1. Measured soil properties organized by pollinator mixture and disturbance regime at the Natural Resources Conservation Service Plant Materials Center in Booneville, AR in 2016 and 2017.

\begin{tabular}{ccccc}
\hline Seed Mixture & $\begin{array}{c}\text { Disturbance } \\
\text { Regime }\end{array}$ & WS Al & WS Na & M3 Co \\
\hline Bamert & Burn & $8.5 \mathrm{bc}^{+}$ & $16.9 \mathrm{e}$ & $0.42 \mathrm{~cd}$ \\
& Control & $9.1 \mathrm{abc}$ & $21.7 \mathrm{bcd}$ & $0.58 \mathrm{a}$ \\
& Disk & $7.8 \mathrm{bc}$ & $20.7 \mathrm{bcde}$ & $0.65 \mathrm{a}$ \\
Hamilton & Burn & $8.2 \mathrm{bc}$ & $30.8 \mathrm{a}$ & $0.47 \mathrm{bc}$ \\
& Control & $7.5 \mathrm{c}$ & $18.5 \mathrm{de}$ & $0.56 \mathrm{ab}$ \\
Holland & Disk & $11.5 \mathrm{a}$ & $24.6 \mathrm{~b}$ & $0.62 \mathrm{a}$ \\
& Burn & $10.0 \mathrm{ab}$ & $21.6 \mathrm{bcd}$ & $0.57 \mathrm{ab}$ \\
& Control & $8.8 \mathrm{bc}$ & $23.2 \mathrm{bc}$ & $0.58 \mathrm{a}$ \\
& Disk & $7.9 \mathrm{bc}$ & $19.4 \mathrm{cde}$ & $0.36 \mathrm{~d}$ \\
\hline
\end{tabular}

Different letters within a column indicate differences at $p \leq 0.05 .{ }^{\dagger}$ WS $=$ water-soluble; M3 = Mehlich-3 extractable.

\subsection{Dual-Use Pollinator and Biomass Properties Based on Seeding Mixture and} Disturbance Regime

As a theoretical exercise, the authors aimed to evaluate the dual-use potential of pollinator mixtures (their ability to provide pollinator habitat while supplying feedstock for bioenergy production). Pollinator mixtures were harvested post-senescence, after the species' bloom period annually. Across all feedstock characteristics, only tissue $\mathrm{C}: \mathrm{N}, \mathrm{N}, \mathrm{ADF}, \mathrm{Mo}$, and Na varied by seed mixture (Table 2), with only C:N varying by disturbance $\times$ seed mixture $(p<0.05)$.

Table 2. Biomass properties by pollinator mixture measured at the Natural Resources Conservation Service Plant Materials Center in Booneville, AR in 2016 and 2017.

\begin{tabular}{cccccc}
\hline $\begin{array}{c}\text { Seed } \\
\text { Mixture }\end{array}$ & $\mathbf{C : N}$ & $\mathbf{N}$ & ADF & Mo & Na \\
\hline & & & \% & & $-\mathbf{m g ~ k g}^{-\mathbf{1}}$ \\
\hline Bamert & $74.9 \mathrm{~b}$ & $0.64 \mathrm{a}$ & $42.4 \mathrm{~b}$ & $0.100 \mathrm{ab}$ & $61.1 \mathrm{~b}$ \\
Hamilton & $108.2 \mathrm{a}$ & $0.45 \mathrm{~b}$ & $47.5 \mathrm{a}$ & $0.075 \mathrm{~b}$ & $268.3 \mathrm{a}$ \\
Holland & $68.2 \mathrm{~b}$ & $0.71 \mathrm{a}$ & $43.0 \mathrm{~b}$ & $0.125 \mathrm{a}$ & $95.1 \mathrm{a}$ \\
\hline
\end{tabular}

Different letters within a column indicate differences at $p \leq 0.05 .{ }^{*} \mathrm{ADF}=$ acid detergent fiber.

\subsection{Pollinator Botanical Composition of Diverse Mixtures following Long-Term} Disturbance Regimes

Five years after establishment, or mid CP42 Pollinator Habitat contract, species composition in terms of flowering species proportion varied by disturbance regime $\times$ seed mixture $(p<0.05)$, with the burned Hamilton and disked Holland plots having the greatest pollinator species percentage, with all other being lower excluding the Holland mixture, control (Figure 1). In addition, grass species and bare ground varied by seed mixture, with the Hamilton mixture having the greatest bare ground percentage and the Bamert mixture having the highest community composition of grass species (Figure 1). Therefore, introducing burning into the Hamilton mixture management and disking into the Holland mixture may result in the greatest percentage of flowering species based on botanical composition in the long term $[19,33]$. 


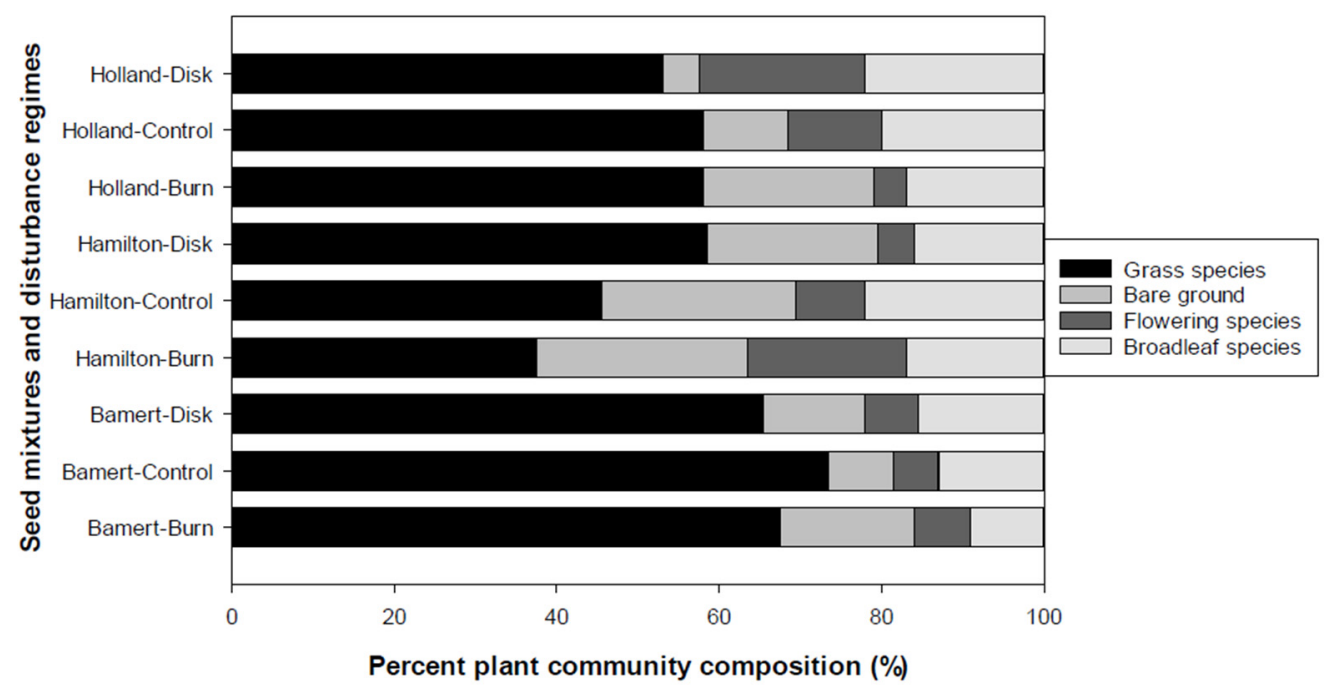

Figure 1. Plant community composition by pollinator mixture and disturbance regime averaged across years (2016-2017) at the Natural Resources Conservation Service Plant Materials Center in Booneville, AR. (Note that broadleaf species = broadleaf non-flowering weeds).

\subsection{Longevity of Pollinator Habitat Based on Management}

To evaluate which mixtures and ecological disturbance regimes extended bloom counts, total bloom counts were quantified. Pollinator bloom count (number per plot) varied $(p<0.05)$ by seed mixture $\times$ disturbance $\times$ year, seed mixture $\times$ year, and year (Figure 2). In general, the number of flowering species (April-July), was greatly reduced following year 2 (a decrease of $81 \%$, on average). The greatest number of flowering species occurred in 2013 for the Bamert mixture and in 2014 for the Holland mixture. The lowest number of flowering species occurred in 2015 and 2017 for the Bamert mixture and in 2015 for the Hamilton mixture. Decreases in 2015 occurred in tandem with ecological disturbance regime implementation. When higher-order interactions were evaluated (seed mixture $\times$ disturbance $\times$ year), disking pollinator residue tended not to increase bloom dates in the first two years; however, by 2017 the greatest total bloom numbers occurred for the disked Holland seed mixture, which was not different than the burned Hamilton mixture long-term (Figure 2).

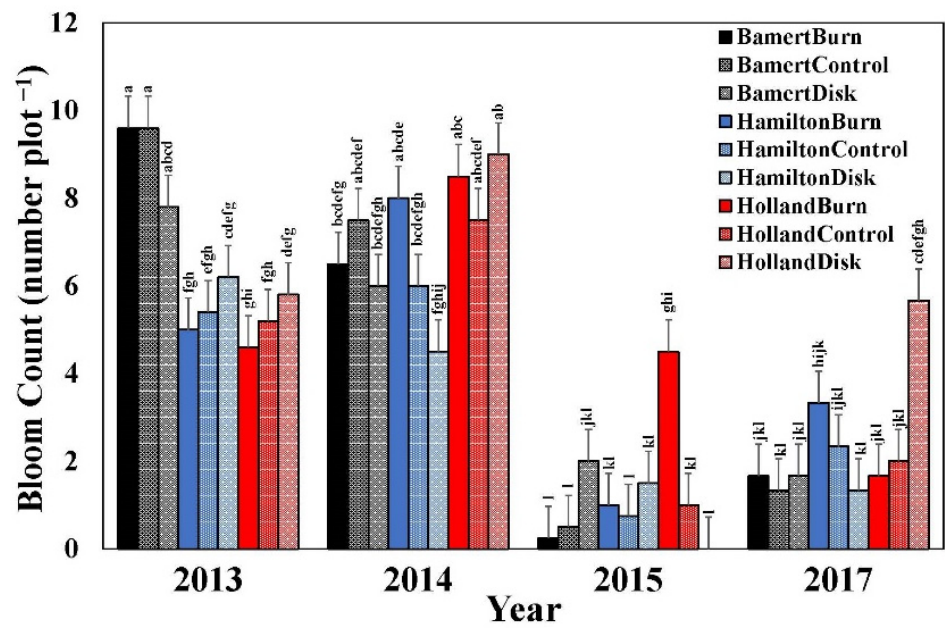

Figure 2. Total bloom count by pollinator mixture and disturbance regime measured at the Natural Resources Conservation Service Plant Materials Center in Booneville, AR in 2013, 2014, 2015, and 2017. Means with the same letter are not different at $p<0.05$. Each error bar represents one standard error. 


\section{Discussion}

\subsection{Environmental Factors Affecting Pollinator Habitat Persistence and Productivity}

There were no apparent soil property trends among disturbances or seed mixtures, with important soil health parameters such as soil $\mathrm{C}$ and nutrients (, $\mathrm{P}$ or $\mathrm{K}$ ) not varying $(p>0.05)$. Therefore, the authors rejected the hypothesis that disking and prescribed burning may affect soil properties and interact to affect seed mixture persistence in the long term, though the effects of vegetation, disturbances, and nutrients on soil carbon may take longer to accrue than our study period.

The apparent decrease in the number of blooming species following the mid-contract disturbance regime required by the Pollinator Habitat program brings into question the efficacy of these ecological disturbance practices. These results indicate that it is likely that disking and burning reduce roots water-soluble carbohydrate storage and spring regeneration potential. However, it is notable that the controls also observed total bloom count reductions in 2015, perhaps owing to soil nutrient limitations, reduced stand longevity, or climatic conditions.

\subsection{Dual-Use Pollinator and Biomass Properties Based on Seeding Mixture and Disturbance Regime}

Overall, the biomass yields did not vary by seed mixture, disturbance regime, or their interaction, although mass was comparable to regional lignocellulosic yields [e.g., corn stover (Zea Mays L.) 2.6 [34] vs. $3.0 \mathrm{Mg}^{-1}$ for pollinator residue in this experiment. The Hamilton mixture under the control resulted in the greatest feedstock $\mathrm{C}: \mathrm{N}$ ratio, with all others being lower (Table 2). Therefore, ecological disturbances such as burning did not increase C:N or feedstock quality, as reduced $\mathrm{N}$ (and greater $\mathrm{C}$ ) is a desirable feedstock trait.

Across all disturbance regimes, the Hamilton seed mixture had the greatest $\mathrm{C}: \mathrm{N}, \mathrm{ADF}$ and $\mathrm{Na}$, with the Holland and Bamert mixtures having lower values (Table 3). Greater ADF in the Hamilton mixture indicates increases in fermentable 5 and 6 sugars for bioethanol conversion, with greater lignin (phenols with high energy densities) occurring in the other two mixtures, which is desirable for direct combustion [35].

Table 3. Biomass C: $N$ ratio by pollinator mixture and disturbance regime measured at the Natural Resources Conservation Service Plant Materials Center in Booneville, AR, in 2016 and 2017.

\begin{tabular}{ccc}
\hline Seed Mixture & Disturbance Regime & C:N \\
\hline Bamert & Burn & $83.8 \mathrm{bc}$ \\
& Control & $64.0 \mathrm{c}$ \\
& Disk & $77.0 \mathrm{bc}$ \\
Hamilton & Burn & $90.7 \mathrm{bc}$ \\
& Control & $141.5 \mathrm{a}$ \\
& Disk & $92.4 \mathrm{~b}$ \\
Holland & Burn & $73.5 \mathrm{bc}$ \\
& Control & $67.6 \mathrm{bc}$ \\
& Disk & $63.6 \mathrm{bc}$ \\
\hline
\end{tabular}

Different letters within a column indicate differences at $p \leq 0.05$.

Though the biomass harvesting of CP42 areas is not allowed according to program guidelines, other private areas managed similar to CP42 areas without active FSA contracts could harvest pollinator mixtures as lignocellulosic feedstock without damaging pollinator habitat and providing comparable biomass for regional feedstocks. However, seeding mixtures should be considered based on desired feedstock usage (biological or thermochemical) [36]. 


\subsection{Ecological Longevity of Pollinator Habitat Based on Management}

The total bloom count data agreed with the botanical composition of these plots (Figure 1), in which the greatest proportion of flowering species occurred in the burned Hamilton mixture and disked Holland mixture treatments as compared to all other combinations. Conversely, the Bamert seed mixture did not persist based on the soils, climate, and disturbance regimes evaluated in this experiment and, consequently, is not recommended.

The lowest bloom counts were observed for the burned and control Bamert, the Hamilton control, and the disked Holland treatment combinations in 2015; however, bloom counts somewhat rebounded in 2017. Overall, if the long-term stability of pollinator blooms is a key consideration for management, the Hamilton mixture residue should be burned mid-contract, while the Holland mixture should be disked, owing to a species-specific disturbance regime preference $[19,33,37]$.

\section{Conclusions}

Adequate pollinator habitat is vital to the economic and ecologic sustainability of food crops in the United States. As a result, the USDA has encouraged landowners to implement conservation practices aimed at maintaining or establishing pollinator habitat via the CRP. This study evaluated three recommended CRP Pollinator Habitat practice mixtures in tandem with widely used disturbance regimes to evaluate which disturbance regime-seeding mixture combination yielded the optimum pollinator habitat in terms of species composition and the greatest period of blooming species, as well as to evaluate the potential of these mixtures to serve as dual-use lignocellulosic bio-feedstocks.

Biomass yield did not vary by seed mixture, disturbance regime, or their interaction, although mass was comparable to regional lignocellulosic yields (e.g., corn stover 2.6 vs. $3.0 \mathrm{Mg}^{-1}$ for pollinator residue). The greater ADF in the Hamilton mixture indicates increases in fermentable sugars for bioethanol conversion, with greater lignin (phenols with high energy densities) occurring in the other two mixtures, which is desirable for direct combustion. Therefore, pollinator mixtures not under active contracts could be harvested as a lignocellulosic feedstock without damaging pollinator habitat and providing comparable biomass for regional feedstocks. However, seeding mixture should be considered based on the desired feedstock usage (biological or thermochemical).

Following establishment, introducing burning into the Hamilton mixture management and disking into the Holland mixture may result in the greatest percent of flowering species based on botanical composition, which was in agreement with bloom counts measured during the growing season, with either regime not adversely affecting important soil health indicators in the mid-South. Our study shows that in some instances, disturbances increased blooming species number, though specific disturbance interacted with species mixtures. Future work should evaluate these optimum seeding mixtures and disturbance regimes in regard to actual pollinator diversity surveys. The results indicated that, for some species and disturbance regimes, re-planting and other management strategies may be needed to maintain stand longevity in the long term to fulfill CRP contract requirements and maintain ecosystem services for pollinators.

Supplementary Materials: The following supporting information can be downloaded at https: / / www.mdpi.com/article/10.3390/agronomy12030549/s1: Table S1: Commercial species mixtures and descriptions for Conservation Reserve Program plantings to promote pollinator habitat.

Author Contributions: Conceptualization, A.J.A. and A.J.; methodology, A.J.A., T.A. and A.J.; software, A.J.A.; formal analysis, A.J.A.; data curation, A.J.A., T.A., A.J.; writing-original draft preparation, A.J.A., T.A.; writing-review and editing, A.J.A., T.A. and A.J.; supervision, A.J.A.; project administration, A.J.A. All authors have read and agreed to the published version of the manuscript.

Funding: This research received no external funding.

Institutional Review Board Statement: Not applicable.

Informed Consent Statement: Not applicable. 
Data Availability Statement: Data are contained within the article or supplementary material.

Conflicts of Interest: Trade names or commercial products mentioned in this article are solely for the purpose of providing specific information and do not infer either a recommendation or an endorsement by the U.S. Department of Agriculture.

\section{References}

1. Thrupp, L.A. Linking agricultural biodiversity and food security: The valuable role of agrobiodiversity for sustainable agriculture. Int. Aff. 2000, 76, 265-281. [CrossRef]

2. Losey, J.E.; Vaughan, D.M. The economic value of ecological service provided by insects. Bioscience 2006, 569, 311-323. [CrossRef]

3. Klein, A.M.; Vaissiere, B.E.; Cane, J.H.; Steffan-Dewenter, I.; Cunningham, S.A.; Kremen, C.; Tscharntke, T. Importance of pollinators in changing landscapes for world crops. Proc. R. Soc. B 2007, 274, 303-313. [CrossRef] [PubMed]

4. Ollerton, J.; Winfree, R.; Tarrant, S. How many flowering plants are pollinated by animals? Oikos 2011, 120, 321-326. [CrossRef]

5. Burkle, L.A.; Marlin, J.C.; Knight, T.M. Plant-pollinator interactions over 120 years: Loss of species, co-occurrence, and function. Science 2013, 339, 1611-1615. [CrossRef]

6. CP42 Pollinator Habitat. Available online: https://www.fsa.usda.gov/Internet/FSA_File/cp42_habitat.pdf (accessed on 3 June 2021).

7. Ellis, J.D.; Evans, J.D.; Pettis, J. Colony losses, managed colony population decline, and Colony Collapse Disorder in the United States. J. Apicult. Res. 2011, 49, 134-136. [CrossRef]

8. Potts, S.G.; Biesmeijer, J.C.; Kremen, C.; Neumann, P.; Schweiger, O.; Kunin, W.E. Global pollinator declines: Trends, impacts, and drivers. Trends Ecol. Evol. 2010, 25, 345-353. [CrossRef] [PubMed]

9. Garibaldi, L.A.; Steffan-Dewenter, I.; Kremen, C.; Morales, J.M.; Bommarco, R.; Cunningham, S.A.; Carvalheiro, L.G.; Chacoff, N.P.; Dudenhoffer, J.H.; Greenleaf, S.S.; et al. Stability of pollination services decrease with isolation from natural areas despite honey bee visits. Ecol. Lett. 2011, 14, 1062-1072. [CrossRef] [PubMed]

10. Pollinator Habitat Initiative. Available online: https://www.fsa.usda.gov/Assets/USDA-FSA-Public/usdafiles/FactSheets/20 15/CRPProgramsandInitiatives/Pollinator_Habitat_Initiative.pdf (accessed on 3 June 2021).

11. Wratten, S.D.; Gillespie, M.; Decourtye, A.; Mader, E.; Desneux, N. Pollinator habitat enhancement: Benefits to other ecosystem services. Agr. Ecosyst. Environ. 2012, 159, 112-122. [CrossRef]

12. Branson, D.H.; Joern, A.; Sword, G.A. Sustainable management of insect herbivores in grassland ecosystems: New perspectives in grasshopper control. Bioscience 2006, 56, 743-755. [CrossRef]

13. Gilgert, W.; Vaughan, M. The value of pollinators and pollinator habitat to rangelands: Connections among pollinators, insects, plant communities, fish and wildlife. Rangelands 2011, 33, 14-19. [CrossRef]

14. Antoine, C.M.; Forrest, J.R. Nesting habitat of ground-nesting bees: A review. Ecol. Entomol. 2021, 46, 143-159. [CrossRef]

15. Chan, K.Y.; Heenan, D.P. The effects of stubble burning and tillage on soil carbon sequestration and crop productivity in southeastern Australia. Soil Use Manag. 2005, 21, 427-431. [CrossRef]

16. Hanula, J.L.; Ulyshen, M.D.; Horn, S. Conserving pollinators in North American forests: A review. Nat. Area. J. 2016, 36, 427-439. [CrossRef]

17. Smith, F.; Brye, K.R.; Gbur, E.E.; Chen, P.; Korth, K. Long-term residue management effects on soil respiration in a wheat-soybean double-crop system. Soil Sci. 2014, 179, 118-129. [CrossRef]

18. Biederbeck, V.O.; Campbell, C.A.; Bowren, K.E.; Schnitzer, M.; Melver, R.N. Effect of burning cereal straw on soil properties and grain yields in Saskatchewan. Soil Sci. Soc. Am. J. 1980, 44, 103-111. [CrossRef]

19. Pollinator-Friendly Best Management Practices for Federal Lands. Available online: https://www.fs.fed.us/wildflowers/ pollinators/BMPs / documents / PollinatorFriendlyBMPsFederalLandsDRAFT05152015.pdf (accessed on 3 June 2021).

20. Norman, C.R.; Brye, K.R.; Gbur, E.E.; Chen, P.; Rupe, J. Long-term management effects on soil properties and yields in a wheat-soybean double-crop system in eastern Arkansas. Soil Sci. 2016, 181, 1-12. [CrossRef]

21. Land Resource Regions and Major Land Resource Areas of the United States, the Caribbean, and the Pacific Basin. Available online: https:/ / www.nrcs.usda.gov/Internet/FSE_DOCUMENTS/nrcs142p2_050898.pdf (accessed on 3 June 2021).

22. Web Soil Survey. Available online: https:/ / websoilsurvey.sc.egov.usda.gov / (accessed on 3 June 2021).

23. Vogel, K.P.; Masters, R.A. Frequency grid-a simple tool for measuring grassland establishment. J. Range Manag. 2001, 54, 653-655. [CrossRef]

24. Van Soest, P.J.; Roberson, J.B. Systems of analysis for evaluating fibrous feeds. In Proceedings of the International Workshop on Standardization of the Analytical Methods in Feeds, Ottawa, ON, Canada, 12-14 March 1979.

25. Determination of Ash in Biomass. Available online: https://www.nrel.gov/docs/gen/fy08/42622.pdf (accessed on 15 June 2021).

26. Gee, G.W.; Or, D. Particle-size analysis. In Methods of Soil Analysis Part 4: Physical Methods, 1st ed.; Dane, J.H., Topp, G.C., Eds.; Soil Science Society of America: Madison, WI, USA, 2002.

27. Tucker, M.R. Determination of phosphorus by Mehlich-3 extraction. In Soil and Media Diagnostic Procedures for the Southern Region of the United States; Donohue, S.J., Ed.; Series Bull. 374; Virginia Agricultural Experiment Station: Blacksburg, VA, USA, 1992; pp. 6-8. 
28. Gomez, E.V.; Schaalje, G.B.; Fellingham, G.W. Performance of the Kenward-Roger method when the covariance structure is selected using AIC and BIC. Commun. Stat.-Simul. Comput. 2005, 34, 377-392. [CrossRef]

29. Saxton, A.M. A macro for converting mean separation output to letter groupings in Proc Mixed. In Proceedings of the 23rd SAS Users Group International, Cary, NC, USA, 22-25 March 1998; pp. 1243-1246.

30. SAS Institute, Inc. SAS 9.2; SAS Institute, Inc.: Cary, NC, USA, 2009.

31. Data Tools: 1981-2010 Normals. Available online: https://www.ncdc.noaa.gov/cdo-web/datatools/normals (accessed on 3 June 2021).

32. Data Tools: Local Climatological Data. Available online: https://www.ncdc.noaa.gov/cdo-web/datatools/lcd (accessed on 3 June 2021).

33. Pollinator Habitat. Available online: https://www.nrcs.usda.gov/wps/PA_NRCSConsumption/download?cid=nrcseprd14312 19\&ext=pdf (accessed on 23 November 2021).

34. Graham, R.L.; Nelson, R.; Sheehan, J.; Perlack, R.D.; Wright, L.L. Current and Potential U.S. Corn Stover Supplies. Agron. J. 2007, 99, 1-11. [CrossRef]

35. Ashworth, A.J.; Keyser, P.D.; Allen, F.L.; Tyler, D.D.; Taylor, A.M.; West, C.P. Displacing inorganic-nitrogen in lignocellulosic feedstock production systems. Agron. J. 2016, 108, 109-116. [CrossRef]

36. Ashworth, A.J.; Weiss, S.A.; Keyser, P.D.; Allen, F.L.; Tyler, D.D.; Taylor, A.; Beamer, K.P.; West, C.P.; Pote, D.H. Switchgrass composition and yield response to alternative soil amendments under intensified heat and drought conditions. Agr. Ecosyst. Environ. 2016, 233, 415-424. [CrossRef]

37. Burning. Available online: https://www.hamiltonnativeoutpost.com/how_to_control_burns.php (accessed on 23 November 2021). 